\title{
APPLICATION OF PERSONALISED SYSTEM OF INSTRUCTION MODEL IN LEARNING DURING THE COVID 19 PANDEMIC TO PHYSICAL EDUCATION LEARNING OUTCOMES
}

\author{
Muhamad Ismam Muhdian', Rian Kurnia', Herman Subarjah³, \\ R. Boyke Mulyana ${ }^{4}$, Hasanul Fitrah $\mathrm{Alba}^{5}$ \\ Universitas Pendidikan Indonesia ${ }^{1,2,3,4}$, Mitra Karya University ${ }^{5}$ \\ ismam2cemen@gmail.com¹, riank60@gmail.com², hermansubarjah@gmail.com³, \\ boyke.mulyana@yahoo.com ${ }^{4}$, hasanulfitrahalba@gmail.com ${ }^{5}$
}

\begin{abstract}
The COVID 19 pandemic that affects almost all countries in the world is a disaster for the entire population of the earth. This disaster caused disruption of all lines including education. As a result of this pandemic came the term distance learning. The study is a combination of distance learning and limited face-to-face learning. The purpose of this study is to find out the application of personalised system of instruction learning model in the learning process during the covid 19 pandemic to the learning outcomes of upper elementary students. The sample used was 5th grade elementary students who numbered 28 people divided into 2 groups. The research method used is the true experimental method with the design of The Randomized Pretest-Posttest Control Group Design. The results of this study obtained the influence of the application of personalised system of instruction learning model in the learning process during the covid 19 pandemic on motivation and learning outcomes in upper elementary students.
\end{abstract}

Keywords: learning model, Personalised System of Instruction, Physical Education.

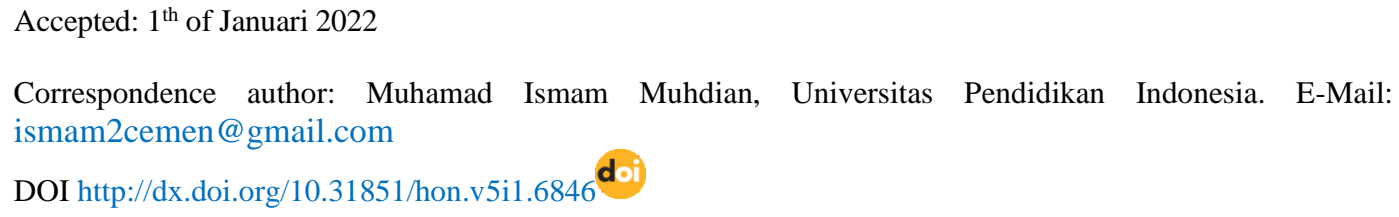

Jurnal Halaman Olahraga Nusantara licensed under a Creative Commons Attribution-ShareAlike 4.0 International License

\section{INTRODUCTION}

Corona Virus Diseases 2019 (COVID-19) is an infectious disease caused by acute respiratory syndrome corona virus 2 (SARS-CoV-2) (Siahaan, 2020). Symptoms that appear to resemble flu, colds, cough, and fever (Amalia \& Sa'adah, 2020). The most dangerous effect of this virus is its very rapid spread. Ina short time, this virus has spread and claimed thousands of lives not only in China but also in various countries in the world such as Italy, Iran, South Korea, Britain, Japan, the United States, Germany, and other countries including Indonesia (Wong et al., 
Muhamad Ismam Muhdian, Rian Kurnia, Herman Subarjah, R. Boyke Mulyana, Hasanul Fitrah Alba, (2022)

Application of personalised system of instruction model in learning during the covid 19 pandemic to physical education learning outcomes

\section{OLATRAGA \\ JURALULHUKROLDIRAQHA \\ Jendral A. Yani Street Lorong Gotong Royong 9/10 U1u \\ Palembang South Sumatera \\ Accredited \\ email jurnal: jurnalhon@univpgri-palembang.ac.id situs web: http://www.univpgri-palembang.ac.id

2020). In order to break the chain of spread of COVID 19, several policies such as stay at home, Work From Home and E-Learning for students and students (Siahaan, 2020). The Ministry of Education and Culture (Kemendikbud) issued a Circular Letter from the Minister of Education and Culture Number: 36962/MPK. A/HK/2020 dated March 17, 2020 on Online Learning and Working from Home in order to Prevent the Spread of Corona Virus Disease (COVID-19) (Argaheni, 2020). The circular from the Ministry of Education and Culture became the basis of distance learning (PJJ) (Wahyudin, Karim, \& Saepurrohman, 2020).

This distance learning program becomes a challenge for teachers to provide learning to students. This condition makes the teacher have to change his teaching and learning strategy. In addition, teachers must also be able to motivate students to keep exercising from home. Giving motivation to individuals with a huge amount of energy, it can be felt when motivation has penetrated oneself (Alba et al., 2019). The use of appropriate teaching methods as well as the behavior and attitude of teachers in managing the teaching and learning process is needed in learning during distance learning programs (PJJ) (Sari et al., 2021). There are many problems in the distance learning process (PJJ) such as limited mastery of information technology by teachers and students, inadequate facilities and infrastructure, limited internet access and lack of budget provision (Aji, 2020). Various ways teachers have done to provide good teaching for students, but in reality not always as expected. Many obstacles experienced by students in the implementation of distance learning ranging from the limitations of learning media, because not all students have smartphones or laptops (Purwanto et al, 2020), lack of internet network connection (Amalia \& Sa'adah, 2020), cost issues related to quota purchases (Fauzi \& Khusuma, 2020), and limitations of adaptability and mastery of information technology by teachers and students (Aji, 2020). Various obstacles that occur make students less interested in distance learning (Setyowahyudi, \&Ferdiyanti, 2020). Lack of interest in student learning makes student learning outcomes decrease. 
Muhamad Ismam Muhdian, Rian Kurnia, Herman Subarjah, R. Boyke Mulyana, Hasanul

Application of personalised system of instruction model in learning during the covid 19 pandemic to physical education learning outcomes

\section{OLAHRAGA}

JURALILHUKCOLIRIQTAA
Jendral A. Yani Street Lorong Gotong Royong 9/10 U1 Palembang South Sumatera

email jurnal: jurnalhon@univpgri-palembang.ac.id situs web: http://www.univpgri-palembang.ac.ic

\section{Accredited}

SINTA 3

A year passed from the beginning of the spread of COVID 19 is a situation that began to becontrolled, some activities can already be done even with strict restrictions on activities. In the world of education some schools have implemented face-to-face learning on a limited basis. This research is a combination of distance learning activities and limited face-to-face learning. In the implementation, students meet and carry out face-to-face learning as much as once in 2 weeks, so that when the first week students carry out face-to-face then in the second week they carry out distance learning. The changing circumstances require teachers to be better prepared to adapt in the learning process with the use of appropriate learning models. Therefore, this study chose the Personalised System of Instruction (PSI) model as a learning model that is considered appropriate for use in this learning process. Personalised System of Instruction (PSI) learning model has the potential to develop student learning independence in tailoring subjects (Juditya et al, 2020). Psi's learning model has differences in the ability to design creative and engaging learning materials, progress toward learning outcomes, learning feedback will soon be known, and individual attention from each in-structure (Metzler, 2000). The purpose of this study is to find out the application of personalised system of instruction learning model in the learning process in the covid 19 pandemic to the learning outcomes of upper elementary students. The material provided in this study is maani physical fitness activity with the main material of heart endurance improvement activity in the subjects of Physical Education class 5.

\section{METHOD}

This study uses true experimental method with the design of The Randomized Pretest-Posttest Control Group Design. The selected population was elementary school Cibatu 01 students who were then selected by 5 th graders who numbered 28 people with the technique of two (n) stage random sampling. The selected 5th graders were divided into 2 groups: the experimental group (PSI model) and the control group (direct instruction model). The data obtained in this study was 
Muhamad Ismam Muhdian, Rian Kurnia, Herman Subarjah, R. Boyke Mulyana, Hasanul Fitrah Alba, (2022)

Application of personalised system of instruction model in learning during the covid 19 pandemic to physical education learning outcomes

\section{OLAHRAGA \\ Jendral A. Yani Street Lorong Gotong Royong 9/10 U1u Palembang South Sumatera \\ Accredited

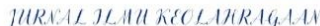 \\ email jurnal: jurnalhon@univpgri-palembang.ac.id situs web: http://www.univpgri-palembang.ac.id}

analyzed and processed with the help of IBM SPSS 21.0 application to determine the improvement of learning outcomes with the Personalised System of Instructionmodel.

\section{RESULT AND DISCUSSION}

The results of this study are presented in Table 1 .

Table 1. Pretest and Posttest Results

\begin{tabular}{llrr}
\hline \multicolumn{1}{c}{ Learning Model } & \multicolumn{1}{c}{ Test } & Skipping & Shutle Run \\
\hline Personalised System & Pretest & 30,81 & 29,79 \\
of Instruction & Posttest & 33,8 & 17,36 \\
& Pretest & 31,34 & 27,14 \\
Direct Instruction & Posttest & 32,83 & 18,29 \\
\hline
\end{tabular}

In table 1, the results of the pretest and postest of both groups of learning models were shown. In the PSI model group on variable skipping pretest results of 30.81 and posttest results of 33.8. On the shuttle run variable the pretest result is 29.79 and the posttest result is 17.36. In the DI model obtained results in skipping pretest 31.34 postest results 32.83 and on the shuttle run variable obtained pretset results 27.17 and posttest 18.29. The results showed that the Personalised System of Instruction model group as an experimental group got better results when compared to the Direct Instruction model group as a control group. Furthermore the results of the dat are depicted in the graph in figure 1 and figure 2.

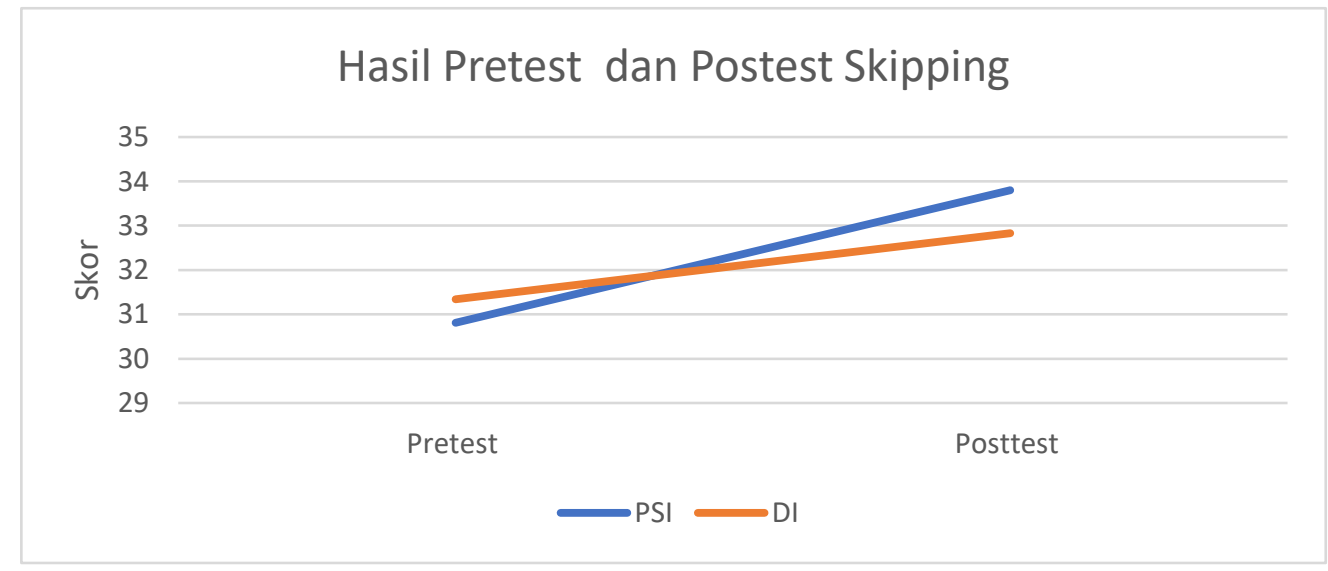

Figure 1. Pretest and Posttest Results Of Skipping Variables 
Muhamad Ismam Muhdian, Rian Kurnia, Herman Subarjah, R. Boyke Mulyana, Hasanul

Application of personalised system of instruction model in learning during the covid 19 pandemic to physical education learning outcomes

\section{OLATRAGA}

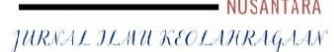

Jendral A. Yani Street Lorong Gotong Royong 9/10 Ulu Palembang South Sumatera

email jurnal: jurnalhon@univpgri-palembang.ac.id situs web: http://www.univpgri-palembang.ac.id

\section{Accredited}

SINTA 3

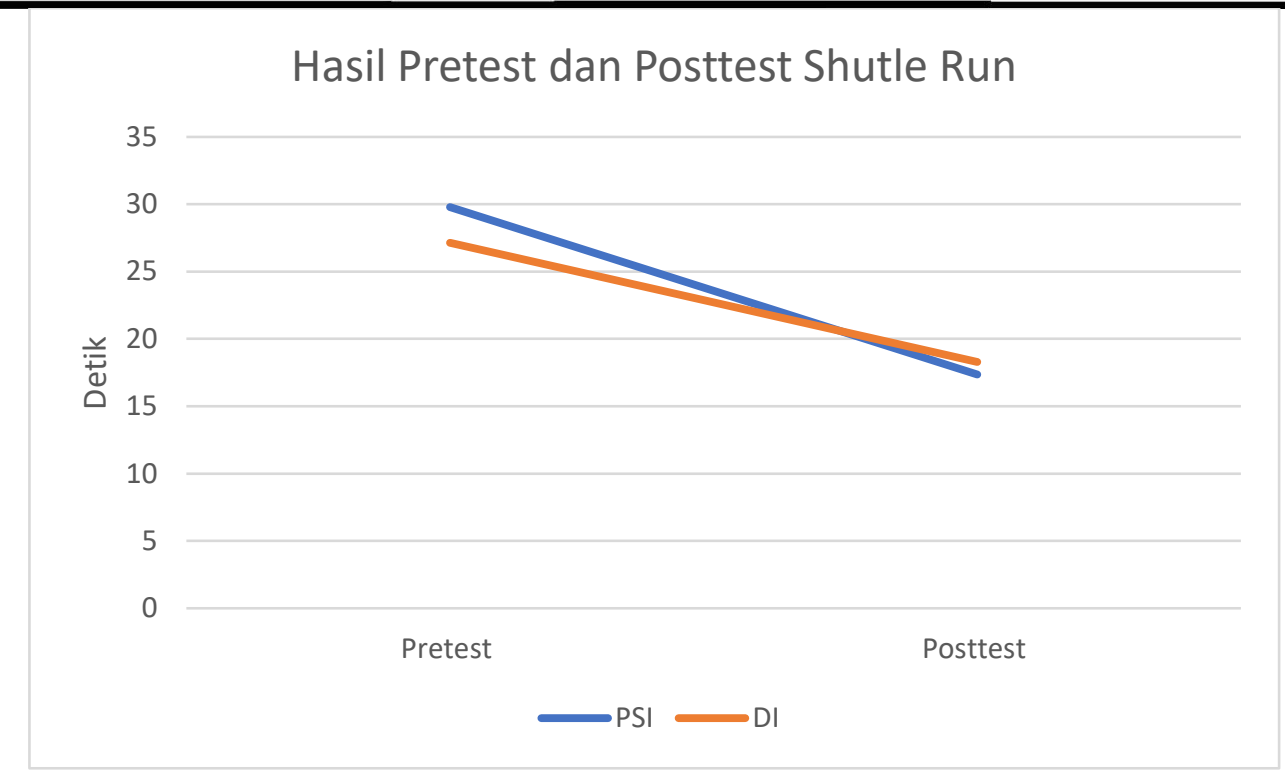

Figure 2. Pretest and Posttest Results of Shutle Run Variables

\section{Discussion}

Based on previously outlined data that there was an increase in student learning outcomes in the experimental group with the Personalised System of Instruction learning model. Thereis a PSI model students feel more free in learning so that students are more able to explore their skills. This is in accordance with the purpose of the PSI learning model developed by Keller \&Sherman (1974) which has a goal to facilitate students so that students can learn more freely, so that teachers can help other students who need help. In addition, the PSI learning model also allows students to learn on their own and at the same time teachers are involved to overcome the difficulties experienced by students who can develop their potential through motion tasks (Ginanjar, 2019). In addition, in the learning of Physical Education teachers are required to provide fun teaching through various forms of games that make students not feel saturated when learning (Azhuri et al, 2021). The characteristics of PSI's own learning model emphasize creative and exciting learning planning that leads to the advancement of student learning outcomes (Metzler, 2000). 
Muhamad Ismam Muhdian, Rian Kurnia, Herman Subarjah, R. Boyke Mulyana, Hasanul Fitrah Alba, (2022)

Application of personalised system of instruction model in learning during the covid 19 pandemic to physical education learning outcomes

\section{OLAHA $\overline{\text { HAGA }}$ \\ Jendral A. Yani Street Lorong Gotong Royong 9/10 U1 Palembang South Sumatera

Psi learning model is a learning model that focuses on students so that students can be more free in their learning practices. In contrast to the direct instruction learning model that is focused on teachers who in their implementation must follow teacher instruction step by step which makes it more difficult for students to express themselves because learning must follow the benchmark that has been given by the teacher. Because teachers play a central role in the DI learning model, this learning success depends on the teacher's image and relies heavily on the teacher's communication style (Shoimin, 2014). While during this pandemic there are many limitations experienced by teachers in the delivery of materials so that teachers cannot monitor students $100 \%$. The limitations of teachers in the use of learning media also make the direct instruction model difficult because students are not given enough opportunities to process and understand the information conveyed especially if the material presented is complex, detailed or abstract. Psi'slearning allows students to learn on their own and at the same time teachers are involved to overcome the difficulties experienced by students who can develop their potential through motion tasks (Ginanjar, 2019). In addition,PSI learning has differences in the ability to design creative and interesting learning materials, progress towards learning outcomes, learning feedback will soon be known, and individual attention from each instructor (Metzler, 2000). Learning with the PSI model, requires students to learn independently by assigning them to observe, understand, and practice the material provided by the teacher, the material is presented in a way that is in accordance with the prepared concept (Juditya et al, 2020). Another advantage of the PSI model is that students' progress can be as fast as they do or slowly as they need (Matzler, 2000).

\section{CONCLUSION}

This research aims to see the effect of the application of personalised system of instruction learning model in the learning process during the covid 19 pandemic on learning outcomes in upper elementary students. In this study, there was a 
Muhamad Ismam Muhdian, Rian Kurnia, Herman Subarjah, R. Boyke Mulyana, Hasanul Fitrah Alba, (2022)

Application of personalised system of instruction model in learning during the covid 19 pandemic to physical education learning outcomes

\section{OLAHRAGA}

JURALULHUKCOL DIRTQHA
Jendral A. Yani Street Lorong Gotong Royong 9/10 U1 Palembang South Sumatera

email jurnal: jurnalhon@univpgri-palembang.ac.id situs web: http://www.univpgri-palembang.ac.id

\section{Accredited}

SINTA 3

significant increase in the effect of the application of personalised system of instruction learning model in the learning process in the pandemi covid 19 period on the learning outcomes of the students of upper elementary school.

Learning outcomes are a way to see the effectiveness of the learning process that has been going on (Arisman \&Okilanda, 2020). Learning outcomes are the result of the teacher and student interaction process and are teacher evaluation materials related to student achievement in the learning process. Student learning outcomes are characterized by a scale of numbers or letters that are a form of grades to show the results of student achievement after the learning process. (Okilanda et al., 2021) The value is used as evidence of student achievement both in terms of knowledge (cognitive), skills (psychomotor), and attitude (affective) which is then used by teachers as an evaluation material of the success of the learning process. In this study, it was found that the application of the Personalised System of Instruction model had a significant influence on improving the learning outcomes of 5 th graders in tailoring subjects.

\section{REFERENCES}

Aji, R. H. S. (2020). Dampak COVID-19 pada pendidikan di indonesia: Sekolah, keterampilan, dan proses pembelajaran. Salam: Jurnal Sosial dan Budaya Syar-i.(7), 5, 395-402. DOI : https://doi.org/10.15408/sjsbs.v7i5.15314

Alba, H. F., Mulyana, \& Subarjah, H. (2019). Pengaruh model latihan weight training dan motivasi latihan terhadap body fat dan body mass index (BMI). Jurnal Ilmu Keolahragaan, 18(2), 112-119.

Arisman, A., \& Okilanda, A. (2020). Pengembangan Diri Melalui Olahraga Panahan. Jurnal MensSana. https://doi.org/10.24036/jm.v5i1.138

Okilanda, A., Dlis, F., Humaid, H., Putra, D. D., Arisman, A., \& Muslimin, M. (2021). Defense Warm-Up Exercise Material for 13-Age Athlete Using Video Technology in Covid-19 Era. International Journal of Human Movement and Sports Sciences, 9(4), 629-634. https://doi.org/10.13189/saj.2021.090404

Amalia, Andina., \& Sa'adah, Nurus. (2020). Dampak Pandemi Covid-19 Terhadap Kegiatan Belajar Mengajar Di Indonesia. Jurnal Psikologi Volume 13 No.2. DOI : https://doi.org/10.35760/psi.2020.v13i2.3572 
Muhamad Ismam Muhdian, Rian Kurnia, Herman Subarjah, R. Boyke Mulyana, Hasanul Fitrah Alba, (2022)

Application of personalised system of instruction model in learning during the covid 19 pandemic to physical education learning outcomes

HALAMAN Jendral A. Yani Street Lorong Gotong Royong 9/10 Ulu OLAHRAGA Palembang South Sumatera

Argaheni, Niken Bayu. (2020). A Systematic Review: The Impact of Online Lectures during the COVID-19 Pandemic Against Indonesian Students. PLACENTUM Jurnal Ilmiah Kesehatan dan Aplikasinya, Vol.8 (2).

Azhuri, Iip Ripai., Purbangkara, Tedi., \& Nasution, Nana Suryana. (2021). Survei Motivasi Belajar Pendidikan Jasmani pada Siswa Sekolah Luar Biasa di Kabupaten Karawang. Jurnal Literasi Olahraga. DOI: https://doi.org/10.35706/jlo.v2i2.4000

Fauzi, I., \& Khusuma, I. H. S. (2020). Teachers' elementary school in online learning of COVID-19 pandemic conditions. Jurnal Iqra': Kajian Ilmu Pendidikan, 5(1), 58-70. https://doi.org/10.25217/ji.v5i1.914

Ginanjar, Agi. (2019). The Effects of Personalized System for Instruction Learning Model on Vocational School Students' Motivation. Jurnal Pendidikan Jasmani dan Olahraga. (Researchgate). https://DOI:10.17509/jpjo.v4i1.13218

Judityaa, Silvy ., Suherman, Adang., Ma'munc, Amung., \& Rusdiana, Agus. (2020). Personalized System of Instruction (PSI) Models: Using Digital Teaching Materials on Learning. publication at: https://www.researchgate.net/publication/339003480

Keller, F. S., and Sherman, J. G. (1974). The Keller Plan handbook. Menlo Park, CA.: W. A. Benjamin.

Purwanto, A., Pramono, R., Asbari, M., Hyun, C., Wijayanti, L., Putri, R., \& Santoso, P. B. (2020). Studi eksploratif dampak pandemi COVID-19 terhadap proses pembelajaran online di Sekolah Dasar. EduPsyCouns: Journal of Education, Psychology and Counseling, 2(1), 1-12.

Metzler, M. W. (2000). Intructional Models for Physi-cal Education. Massachusetts: Allyn and Bacon.

Sari, Ria Puspita., Tusyantari, Nabila Bunnanditya., \& Suswandari, Meidawati. Dampak Pembelajaran Daring Bagi Siswa Sekolah Dasar Selama Covid-19. Prima Magistra: Jurnal Ilmiah Kependidikan. DOI: https://doi.org/10.37478/jpm.v2i1.732

Setyowahyudi, R., \& Ferdiyanti, T. (2020). Keterampilan guru PAUD Kabupaten Ponorogo dalam memberikan penguatan selama masa pandemi COVID-19. Jurnal Golden Age, 4(1), 100-112.

Shoimin, Aris. (2014). Model Pembelajaran Inovatif Dalam Kurikulum 2013. Yokyakarta: AR-ruz media. 
Muhamad Ismam Muhdian, Rian Kurnia, Herman Subarjah, R. Boyke Mulyana, Hasanul Fitrah Alba, (2022)

Application of personalised system of instruction model in learning during the covid 19 pandemic to physical education learning outcomes

\section{OLATRAGA}

JURALILHUKCOLDIRAQTH
Jendral A. Yani Street Lorong Gotong Royong 9/10 U1 Palembang South Sumatera

email jurnal: jurnalhon@univpgri-palembang.ac.id situs web: http://www.univpgri-palembang.ac.id

\section{Accredited}

SINTA 3

Siahaan, Matdio. (2020). Dampak Pandemi Covid-19 Terhadap Dunia Pendidikan. Jurnal Kajian Ilmiah (JKI). Available Online at http://ejurnal.ubharajaya.ac.id/index.php/JKI

Wahyudin D, Karim A, Saepurrohman A. (2020). Pengelolaan Pembelajaran Jarak Jauh : Kajian Dasar Hukum dan Respon Mahasiswa. Digit Libr UIN Sunan Gunung Jati [Internet]. 2020;1-11. Available from: http://digilib.uinsgd.ac.id/30652/

Wong, G. L. H., Wong, V. W. S., Thompson, A., Jia, J., Hou, J., Lesmana, C. R. A., Susilo, A., Tanaka, Y., Chan, W. K., Gane, E., Ong-Go, A. K., Lim, S. G., Ahn, S. H., Yu, M. L., Piratvisuth, T., \& Chan, H. L. Y. (2020). Management of patients with liver derangement during the COVID-19 pandemic: An Asia-Pacific position statement. The Lancet Gastroenterology and Hepatology, 5(8), 776-787. https://doi.org/10.1016/S2468-1253(20)30190-4 